\title{
Contingent Fees in California
}

\section{Max Radin*}

A LL LAwYers are rich. They get huge fees. When they are attorneys for a decedent's estate, they take the whole estate. They crack the walnut, give each litigant one of the two halfshells, and eat the kernel themselves. Or else, it is an oyster which they eat, giving the litigants the somewhat less edible valves. All this must be true because laymen have said it about lawyers for many hundred years.

It must, therefore, be something of a surprise to laymen to discover that lawyers - a great many lawyers-are willing to work, and work hard, for nothing. Or at any rate for an excellent chance of gettimg nothing. Not only will they work hard, but they will put themselves to considerable expense which may very well never get repaid. And when laymen discover that the lawyers who do this are assailed by other lawyers for the impropriety of their conduct, they will doubtless be confirmed in their conviction that everything that lawyers do which sounds well-disposed or benevolent to laymen is bitterly opposed by the generality of the profession.

That, we must remember, is an important and often neglected element in the question of the contingent fee; the contrast between the popular and the professional point of view on the subject. To the laity the offer of a lawyer to conduct litigation wholly or partly at his own expense and to be paid only if he is successful in obtaining not merely a judgment but an actual recovery, is, in the main, taken to be a laudable and beneficial proposal. Among lawyers, on the other hand, the arrangement for a contingent fee was at one time not only void, but constituted a criminal offense, the offense of champerty. That is still the rule in England. And at the present time, in places where it is not void, it is looked upon with disfavor, not to say with contempt.

*A.B. 1899, College of the City of New York; LL.B. 1902, New York University; Ph.D. 1909, Colunbia University. Professor of Law, University of California. Author of The Legtslation of The Greess and Romans on Corporations (1909); Handbook of Rodian Law (1927); Triad of Jesus Christ (1929); Handbook of angloAMTERTCAN Legal History (1936); The LaW and Mr. SAITtH (1938); ManNers and Morais of Business (1939); LaW as Logic AND ExperIence (1940); and of articles in legal periodicals.

1 The history of maintenance is discussed in the writer's article, Maintenance $B y$ Champerty (1935) 24 CaLIF. L. REV. 48. 
The reason for that is partly historical. The common-law offense of champerty was not much practiced by lawyers whose small numbers and high fees made it unnecessary for them to speculate on the result of litigation. ${ }^{2}$ Champerty was discreditable for the very simple reason that during the Middle Ages all speculation was discreditable. It had more than a touch of usury in it. The half-clerical profession of the law would be particularly opposed to it. It was of course evaded just as usury was evaded in some cases by members of the clergy. But when speculation and the charging of interest became respectable —or at least tolerable — in ordinary business, it remained a gross impropriety for lawyers, just as lawyers' writings continued to disapprove of interest long after the statute had legalized it. ${ }^{3}$

Other elements combined to strengthen the opposition. It was rationalized as a repugnance to stirring up litigation which speculation on the results of lawsuits might well do. It was deplored because tradesmen speculated, and lawyers were gentlemen, and not tradesinen. And it may well be the fact that contingent fees multiplied during the nineteenth century as a by-product of the Industrial Revolution which brought into sharp contrast the group of lawyers who were willing to take cases on contingencies and those who were not. The latter represented the defendant railroads, steamships, factories, power compames. They were the admitted leaders of the bar. The former were the young lawyers struggling to make a living. They could scarcely help being an inferior class.

But this same factor decided the struggle in favor of the contingent fee. There were far too many persons who could pay no retainers and far too many lawyers who could not afford to insist on them. In a democratic community there was no question that so definite a demand would be successful.

In England the contingent fee is still illegal. ${ }^{4}$ Whether it would justify a prosecution for champerty is another matter. ${ }^{5}$ But that it is void and that a solicitor who has made such a bargain can neither

2 The Statute of Westminster I which first forbade champerty does not mention attorneys, but does mention royal officers. 3 EDw. I (1275) cs. 25, 28.

3 Cf. Rasterr, Teranes de LA Ley (1708) 546-547, s.v. Usury.

4 Wiggins v. Lavy (1928) 44 T. L. R. 721; Haseldine v. Hosken [1933] 1 K. B. 822. Cf. Solicitors Act, 1932, $22 \& 23$ GEo. V, c. $37, \S 63$ (1), which repeals the provision of the Attorneys' and Solicitors' Act, 1870, 33 \& 34 Vicr., c. 28, § 4 et seq.; cf. also Wild v. Simpson [1919] 2 K. B. 544, 550-551.

5 It seems to be obsolete as a criminal offense. 3 STEPHEN, A History or THE Crmmtala Law of Engtand (1883) 234. 
recover on it nor on a quantum meruit for his actual services is undoubted. ${ }^{6}$

In the United States, quite generally, the contingent fee is established in nearly all jurisdictions. In a few states there seems to be no specific case or statute expressly authorizing it, but there is also no statutory or judicial rejection of it.

The courts of Massachusetts alone, so far as I can find, still treat the contract for a contingent fee as void. ${ }^{7}$ However, even in Massachusetts such a contract is not per se a wrongful act, nor is the fact that a plaintiff has promised a contingent fee to his attorney a bar to recovery on the claim.

In most states there is express authority in decided cases that a contract for a contingent fee is a valid one. It permits an action on the contract by the attorney against his client, and a fortiori could not be made the basis of a prosecution against either or used as a plea against the claim of the client.

The case for and against a contingent fee, if we disregard considerations of history and what may be called snobbery, may be briefly summarized. The contingent fee certainly imcreases the possibility that vexatious and unfounded suits will be brought. On the other hand, it makes possible the enforcement of legitimate claims which otherwise would be abandoned because of the poverty of the claimants. Of these two possibilities, the social advantage seems clearly on the side of the contingent fee. It may in fact be added by way of reply to the first objection that vexatious and unfounded suits have been brought by men who could and did pay substantial attorneys' fees for that purpose.

Although the contingent fee is deflnitely established in the vast majority of American jurisdictions, its inheritance of discredit is still an element to be considered. It has been supported generally as a measure of social need. The persons injured in "accidents" are often unable to pay a retainer and the fact that these situations are

${ }^{6}$ If, however, tased costs had actually been incurred by a valid retainer, a subsequent champertous agreement does not prevent their recovery. Grell v. Levy (1864) 12 W. R. 378. The report in (1864) 16 C. B. (N. S.) 73 is not quite clear.

7 Holdsworth v. Healey (1924) 249 Mass. 436, 144 N. E. 386. However, a contingent fee in Massachusetts is champertous only if it is to be paid solely from the amount recovered, without any personal hability of the client. If le is personally-thougl contingently-liable, the agreement is valid. Blaisdell v. Ahern (1887) 144 Mass. 393, 11 N. E. 681 ; Reed v. Chase (1921) 238 Mass. 83,130 N. E. 257; cf. Note (1905) 18 Harv. L. REv. 223. 
called "accidents" indicates of itself the difficulty of establishing liability. But as a matter of fact, it is possible to face the problem more directly. It is no news to lawyers that there may be claims which the holders sincerely and correctly regard as valid but in which recovery is doubtful. Is there anything essentially immoral or unethical in engaging a lawyer who shares his client's conviction that the claim is well-founded, and who will assume the risk of prosecuting it for the chance of a fee? It is unethical if speculation as such is unethical. Speculation is a crime, we are told, in Soviet Russia. And it is unethical, if lawyers must sedulously avoid any comparison with businessmen. Whether this view lies in the mouth of some of those who most vigorously disapprove of the contingent fee is another question.

So far as California is concerned, there is no question about the legality of the contingent fee as such. ${ }^{8}$ An agreement between lawyer and client for such a fee is actionable, and making such an agreement is not an impropriety that will subject an attorney to discipline. Further, the attorney may advance court costs and disbursements and get them back ouly if he is successful.

But if such agreements are not invalid per se, it does not follow that all contingent fees are lawful in California. There is first the striking exception that a contingent fee contract in a divorce action is void. This was decided in Neroman $v$. Freitas. ${ }^{\circ}$ This was an action for specific performance. The plaintiff wife in the divorce action had agreed to give her attorney, $L$, one-third " 'of all amounts recovered or received" "10 as the wife's portion of the community property. The court held that specific performance would not lie, first, because it would be "not only inequitable, but unreasonable and unjust"11 to decree specific performance, since the attorney had already received "reasonable compensation." And, secondly, the court notes that so far as the contract involves personal property, specific performance would not lie under any circumstances.

But more important for our purposes, the court declares that, in general, contingent fees in divorce actions are against public policy. The law does not encourage divorce actions even when causes of divorce exist and therefore the rationale of the contingent fee, which

8 The most recent statement is that in Wilhelm v. Rush (1937) 18 Cal. App. (2d) $366,369,63$ P. (2d) 1158, 1160. As early as Mathewson v. Fitch (1863) 22 Cal. 86, 95, it was stated: ". . . the offense of maintenance is unknown to the laws of this State."

9 (1900) 129 Cal. 283, 61 Pac. 907.

10 Ibid. at 285,61 Pac. at 907.

11 Ibid. at 289, 61 Pac. at 909. 
is that such a fee facilitates the enforcement of just claims, fails in this case. In this case the court cites cases in Illinois, Indiana, Missouri, and Michigan.

The reasoning is sound enough, provided it is supplemented by the fact that, where a divorce is both legally justified and socially desirable, there is a definite procedure by which an impecunious wife may obtain counsel fees pendente lite.

There is another limitation on the validity of a contingent fee. There is such a thing as an excessive fee. The cases in California often use language which makes it difficult to understand what the test of excessiveness in attorneys' fees is, but there have been cases in which fees have been found to be excessive and attorneys have been disciplined for denianding then..$^{12}$ It seems to be clear that a fee which may be the basis for punishing an attorney cannot be the basis for an action by the attorney against his client.

If, therefore, a fee which is specifically contracted for, may, none the less, be excessive, it seems that there must be such a thing as an excessive contingent fee. If the contract were for nine-tenths of the amount recovered, it would be clearly excessive. What if it were three-quarters or two-thirds? We should hesitate to assert flatly that such a fraction would be necessarily excessive, but the probability is that it would be so considered, though there are doubtless conceivable situations in which so large a proportion might seem permissible.

When the recovery is large, a contingent fee of one-half or onethird will seem excessive to laymen, and if the only basis for fees is the actual time and effort enployed by counsel or the degree of skill exhibited, one-half or one-third of a large amount is often clearly excessive. But, as has been frequently pointed out, no objective standard of measurenient for professional skill has ever been devised. ${ }^{13}$ It is really inipossible to measure skill at all, and a "proper fee" nuay be as elusive as the iustum pretium of medieval economists which nineteenth century analysts so eniphatically repudiated.

Clearly a contingent fee and an excessive fee are not convertible ternis and there have been as many complaints of excessive fees which were not dependent upon the result of litigation as of those which

12 Goldstone v. State Bar of Calif. (1931) 214 Cal. 490, 6 P. (2d) 513, (1932) 80 A.L.R. 701 (workmen's compensation case, in which by statute the fees must be reasonable); Newmire v. Ford (1913) 22 Cal. App. 712, 136 Pac. 504; cf. Barbee v. The State Bar (1931) 213 Cal. 296, 2 P. (2d) 353.

13 Stuart v. Preston (1934) 2 Cal. App. (2d) 310, 38 P. (2d) 155; cf. m general Cad. Code Crv. Proc. $\S 1021$. 
were so dependent. Indeed for the defeated litigant in any case, any fee at all doubtless seems excessive. The point is, of course, that contingent fees are generally arranged with litigants who are people of limited means. They consequently are not in as favorable a position to bargain for legal services as persons who can pick and choose counsel. They have a choice of persons but a definite custom has grown up that if a lawyer takes a case on a contingency he may demand a considerable share of the amount recovered.

There is another limitation on all attorneys' fees which applies therefore to contimgent fees as well. By section 1509 of the Probate Code, "A contract for attorney's fees for services in litigation, made by or on behalf of a minor, is void unless the contract is approved by the court in which the litigation is pending. ..." Since minors are frequently plaintiffs in negligence actions in which conditional fee contracts are common, it follows that a great many contingent fees will be subject to court scrutiny in order to be valid.

What test will the courts apply? Evidently that of reasonableness, since contracts made through a guardian ad litem must be reasonable. And reasonableness is a test different from that applied to contracts for fees in ordinary cases. Although courts have declared that lawyers must not charge excessive fees and will punish lawyers for doing so, they have also declared that their fees may be nuch larger than the "reasonable value" of their services, if such larger fees have been contracted for..$^{14}$ The comfortable theory is announced that the contractual fees is sometimes less than the value of the services rendered and that therefore these fees will strike a balance of reasonableness in the long run..$^{15} \mathrm{We}$ are familiar with this type of rationalization in other connections, and we may be sure it is not based on a careful statistical study.

We may say, therefore, that a contract for fees, contingent or otherwise, made with a not incompetent adult may be unreasonably large without being excessive, that is to say, may be larger than the fees an attorney would get if he had made no agreement and sued for the reasonable value of his services. Apparently no stipulated fee will be excessive, unless there is some indication of overreaching, abuse of a confidential relationship, or bad faith in general.

These seem to be the only qualifications which California courts or statutes have made on the contingent fee. Agreements for such fees may include a stipulation that the attorneys shall pay the costs

14 Herrscher v. State Bar (1935) 4 Cal. (2d) 399, 49 P. (2d) 832.

15 Reynolds v. Sorosis Fruit Co. (1901) 133 Cal. 625, 66 Pac. 21. 
although such a condition makes the contract champertous even in jurisdictions in which the contingent fee is allowed. The contract may call for a share in the actual res sued for, even when this is land, and in such a case-if there is no other equitable bar-it may be enforced specifically. It should be remembered that this arrangement for a division of land in controversy-campi partem - was the original form of champerty and gave it its name.

The form of contracts im which agreements for contimgent fees are embodied usually provides that the suit must not be dismissed or compromised without the consent of the attorney. A provision of this sort is, however, void in California. Litigants may dispose of the action in any way they like and the attorney's only recourse is to sue his client for the agreed compensation.

A lawyer in Califorma, consequently, may lawfully make a contract for a contingent fee, within the limitations indicated. How much protection will the court allow the lawyer beyond the fact that he may sue his client for his fee and enjoy all the remedies creditors are clothed with for that purpose?

In jurisdictions in which there is an attorney's lien, the protection is ample and complete. The attorney may enforce his lien against the judgment and in this case he will be assured of payment, if the defendant is solvent. But there is no attorney's lien in California. If the money obtained by judgment or settlement comes into his hands, and he turns it over to his client less the amount of his fee, the client could scarcely by action or by summary proceedings demand the entire amount, since there is a valid set-off. But if the amount is paid to the client, there is no way in which the lawyer can prevent such payment or suspend it until his claim is satisfied. He can bring an action and attach the fund, if it is in attachable form, but that implies that the client has refused to pay the amount. Generally, when the attorney has to resort to such a process, the fund is dissipated before it can be attached.

This, of course, is the case whether the fee is contingent or not. Recently the attempt has been made to surround the contingent fee contract with safeguards for the attorney which do not exist in the ordinary fee-contract. A section of the Code of Civil Procedure (section 284) was enacted which provided:

"The attorney in an action or special proceeding may be changed at any time before or after judgment or final determination, as follows:

"1. Upon the consent of both client and attorney, filed with the clerk, or entered upon the minutes; 
"2. Upon the order of the court, upon the application of either client or attorney, after notice from one to the other except that in all civil cases in which the fee or compensation of the attorney is contingent upon the recovery of money, in which case the court shall determime the amount and terms of payment of the fee or compensation to be paid by the party."

This section has just been declared unconstitutional by the supreme court in the case of Echlin v. Superior Court $t^{16}$ on the ground that it singles out fees which are contingent upon the recovery of money, and does not include all contingent fees. This was declared to be an unreasonable classification. It is hinted in the case that if the entire class of contingent fee contracts was included, the classification might be reasonable enough. The court declined to pass on the contention that the power granted to the court also violated the constitutional guaranty of a jury trial.

The code section is concerned only with the right of a client to change his attorney after having made a contingent fee contract with him. It may be that this is the situation in which the chance of an attorney to get his fee paid, when it is contingent, is most frequently imperiled.

Nothing is said in the code section of a lien. But it seems to be implied that if the court fixes compensation, the judgment can hardly be satisfied unless this compensation is paid.

Obviously the common-law charging lien would cover the situation. But it has long been declared that no such lien exists in California. This was declared as early as the case of $E x$ parte $K y l e{ }^{17}$ and has been reiterated in many cases thereafter, all of which cite Ex parte Kyle. It does not seen, however, that the basis of decision in Ex parte Kyle has been fully analyzed.

This case and the more recent ones which reaffirm it are based on the distinction between "costs" and "fees." There was a lien for "costs" at the common law, says Ex parte Kyle, and such a lien is not rejected. But there was no lien at the common law for the value of the services performed by the attorney, like the lien of those who performed labor on chattels or like the statutory mechanics' liens for services rendered in building or repairing structures on land.

The distinction is based on a statement in Grahaun's Practice, published in $1832 . .^{18}$ But the fact is overlooked that in England

16 (1939) 13 Cal. (2d) 368, 90 P. (2d) 63, (1939) 28 CarIF. L. Rev. 92.

17 (1850) 1 Cal. 331.

18 Graeam, A Treatise on the Practice of the Supreme Court of the State of NEw YORE (1832) 30-34. It must be pointed out, however, that the fact that in 
"costs" includes what we call fees. Not only do the "costs" for which the English solicitor has a lien on the cause of action include the remuneration for his services, but they are by statute made the sole remuneration he may demand for the actual conduct of litigation. ${ }^{19}$

These "costs" were thus statutory at the time of Ex parte Kyle, and the court was right in pointing out that in California there were no "costs" granted by statute to the attorney. But there had been costs in England before the statute fixed them and the lien for this purpose is older than the statute.

It is somewhat erroneously stated in some cases that the coststhat is, the fees-of the attorney at common law where wholly statutory. That is not the case. The judgment for the plaintiff regularly mcluded these costs even before the Statute of Gloucester in $1278,{ }^{20}$ and since $1531^{21}$ the defendant had a corresponding and quite general right to recover costs if the plaintiff was nonsuited. What later statutes did was to limit the costs to fixed sums. They did not in any sense create the right to costs.

It may be noted that in at least two instances in California, that is, suits for partition and condemnation proceedings, the attorney's compensation is fixed by statute and is protected by a lien on the award. ${ }^{22}$

Evidently an attorney's lien for his compensation, whether it is called "costs" or "fees," serves all the purposes of a contingent fee. We have, therefore, what must be called a not uncommon example of indirection when English lawyers boast of their lofty standards in repudiating the contingent fee. Their lien for "costs" renders the contingent fee unnecessary.

The American Bar Association in its Canons of Professional Ethics ${ }^{23}$ has proposed that all contingent fees be subject to scrutiny

Ex parte Kyle it was assumed that "costs" had always been statutory and that they were different from fees, does not qualify the rule that the attorney's lien as such does not exist in California. This rule is based on the many cases which have followed Ex parte Kyle, and is as well-established as though the historical foundation of that case had been umimpeachable.

19 Agreements between solicitor and client for remuneration are valid but are subject to tests of reasonableness. The "taxed" costs are in force in the absence of agreement.

$206 \mathrm{EDw} . \mathrm{I}, \mathrm{c} .1$.

2123 HEN. VIII, c. 15.

22 CaL. Code Crv. Proc. $\$ \$ 763,1255$. In condemnation proceedings the award, including attorney's fees, is paid to the party to the action, not to the attorney. Keck v. Keck (1933) 219 Cal. 316, 26 P. (2d) 300.

23 (1936) Canon 13, p. 8. 
and approval by the court, just as is done in California for such contracts made on behalf of minors. If this were generally adopted, the court scrutiny would doubtless soon follow standard rules of reasonableness in fees, and we should have what would be an equivalent of a statutorily fixed fee-in this instance a contingent fee. With the example of the fixed contingent fee in condemnation proceedings and partition suits, there seems no very good reason why a contingent fee approved by the court should not be protected by a lien for the attorney.

- The attorney's liens, both the retaiming lien which protects the attorney when counsel is changed and the charging lien which protects. him when a recovery is obtained, are established in a number of American states and do not depend on statutory "costs" but cover whatever claim for compensation the attorney may have. Several attempts have been made to establish such liens in California. One of them resulted in the code provision recently struck down by the court in Echlin v. Superior Court. ${ }^{24}$ Other attempts have net with determined opposition. In the last meeting of the Conference of Delegates, a committee was appointed to propose a revision of the code section declared unconstitutional.

Attention must be called to a statement in the recent case of City of Los Angeles v. Knapp: ${ }^{25}$ "The rule in this state, uulike that in other jurisdictions, is that an attorney generally has no lien on a judginent procured by his professional services in the absence ofian express agreement for a lien." This is, it is true, merely a dictum since the case itself dealt with a wholly different matter and is direct authority only in regard to conflicting claims in successive assignments of fees in condemnation proceedings. But if this dictum becomes generally accepted, we should have a rule that rendered a statutory lien unnecessary. A lawyer would merely be required to mcorporate into his contract a provision for a lien in order to provide himself with everything the statute could give him. And since contingent fee contracts follow set forms, we may be sure that a provision for a lien would soon be a part of that form.

24 Supra note 16.

25 (1936) 7 Cal. (2d) 168, 173, 60 P. (2d) 127, 130. (Italics added.) In Tracy v. Ringole (1927) 87 Cal. App. 549, 262 Pac. 73, a lien was actually contracted for and held to be valid. But the specific point has not been passed on by the supreme court. Cf. Cassetta v. Del Frate (1931) 116 Cal. App. 255, 2 P. (2d) 533, in which a specific lien was stipulated for in a judgment to be recovered for negligence. The court rejected the lien since it did not affirmatively appear that the cause of action was assignable. 
Can the attorney reach the same result by having an interest in the cause of action assigned to him? Hardly in negligence cases, because a cause of action in tort is not assignable. And when it is assignable, it may coine within the very narrow field to which champerty in California has been restricted. ${ }^{26}$

By a provision in the Business and Professional Code ${ }^{27}$ any attorney who "directly or indirectly, buys or is interested in buying any evidence of debt or thing in action, with intent to bring suit thereon, is guilty of a misdemeanor." The provision is clearly aimed at sonie types of collection agencies, and has been recently interpreted by a number of cases. ${ }^{28}$

But if it might be difficult to assign a part of the cause of action to an attorney, the question of his interest in it nuay be raised in another way. The client, it is expressly declared, may-subject to the qualification noted in section 284 of the California Code of Civil Procedure-dismiss his attorney at any time. ${ }^{29}$ He may even do so, it has been held, arbitrarily and without sufficient cause. But there is an exception based on the ordinary rule of agency that no such power to dismiss exists if the attorney has acquired an interest in the subject matter of the litigation.

Evidently if the attorney was from the beginning part owner of the cause of action and was suing partly for himself and partly as attorney for his associate, he could not be dismissed. It is implied by the statenient in City of Los Angeles v. Knapp that an interest could be acquired in the course of the litigation. A lien would surely be an interest, and if a lien could be stipulated for as the case of City of Los Angeles v. Knapp suggests, the principle of irrevocable agency would prevent the dismissal of the attorney. ${ }^{30}$

26 It has been held that a valid and.enforceable contingent fee contract transfers to the attorney an equitable interest in any judgment which may be secured. Howell v. Budd (1891) 91 Cal. 342, 27 Pac. 747; Kelly v. Smith (1928) 204 Cal. 496, 268 Pac. 1057; Gomez v. Superior Court (1933) 134 Cal. App. 19, 23, 24 P. (2d) 856, 857, and the cases in the previous note. How these cases are to be reconciled to the doctrine that there is no lien for the attorney in California is not quite clear.

$27 \$ 6129$, formerly CAL. PEN. CODE $\$ 161$.

28 Cohn v. Thompson (1932) 2 Cal. Supp. 44, (1932) 128 Cal. App. 783, 16 P. (2d) 364; Crawford v. Engler (1933) 131 Cal. App. 374, 21 P. (2d) 460. The problem of intent is discussed in Bulkeley v. Bank of Calif. (1S85) $68 \mathrm{Cal}$. S0, 8 Pac. 643, and in The Holladay Case (C. C. D. Ore. 1886) 27 Fed. 830, 840. Cf. Note (1937) 10 So. CatIF. L. Rev. 491, 494.

29 Zurich etc. Ins. Co. v. Kinsler (1938) 12 CaI. (2d) 98, 81 P. (2d) 913, (1938) 27 CaLIF. L. REv. 75.

30 Todd v. Superior Court (1919) 181 Cal. 406, 419-420, 184 Pac. 684, 689, (1920) 7 A. L. R. 938, 947 ; Scott v. Superior Court (1928) 205 Cal. 525, 532, 271 Pac. 906, 909. 
Those groups of lawyers who have frequent occasion to use contingent fees will perhaps urge that court scrutiny of fees is as desirable in situations in which there is a non-contingent fee fixed by agreement as in the case of a contingent fee. It is not very likely that they will succeed in convincing the bar of this but they may well carry conviction to the laity. In fact, it would not be hard to convince the public that all fees should be contingent and all of them subject to court scrutiny as to reasonableness.

The normal attitude of the layman toward legal procedure is that the result is inevitably contingent. The uncertainty of trials and judgments is proverbial. There seems, therefore, nothing unnatural or improper in the assumption that the payment should be as contingent as the result. The uncertain element, however, in most of the situations in which contingent fees are chiefly used, is not in the law, but in the facts, or rather in the success of a lawyer in persuading a judge or jury that the facts were of a special sort. Where the law is really uncertain, that is to say, in doubtful and intricate matters in which ample and weighty authority can be found for contradictory propositions, contingent fees are rarely met with. In cases like these, lawyers are paid without reference to success and, it is to be hoped, are paid well and in advance.

It would be better for both the bar and the public if the need for contingent fees was not merely recognized, as it can scarcely help being, but if it was regarded, not as a regrettable decadence from a loftier standard, but as an institution that serves an important purpose. It would be easier to correct its abuses, if those lawyers who are fortunate enough to be assured of ample compensation whether they are successful or not in a speciflc case made an effort to understand all the implications of the situation in which men and women find themselves who caimot pay retainers and refreshers but whose need for a just settlement of their claims is no less urgent by reason of that fact. 